\title{
DO THE SUBSIDIES HELP THE YOUNG FARMERS? THE CASE STUDY OF THE CZECH REPUBLIC
}

\author{
Marie Šimpachová Pechrová1, Ondřej Šimpach² \\ ${ }^{1}$ Institute of Agricultural Economics and Information, Mánesova 1453/75, 12000 Prague 2, Czech Republic \\ ${ }^{2}$ Faculty of Informatics and Statistics, University of Economics Prague, W. Churchill Sq. 4, 13067 Prague 3, Czech \\ Republic
}

Link to this article: https://doi.org/10.11118/actaun202068010255

Received: 10. 9. 2018, Accepted: 7. 1. 2020

To cite this article: ŠIMPACHOVÁ PECHROVÁ MARIE, ŠIMPACH ONDŘEJ. 2020. Do the Subsidies Help the Young Farmers? The Case Study of the Czech Republic. Acta Universitatis Agriculturae et Silviculturae Mendelianae Brunensis, 68(1): 255-262.

\begin{abstract}
To ensure the generation renewal in the European Union there are subsidies for setting up of young farmers' businesses and the retirement scheme and top-up direct payments. In the Czech Republic are provided subsides to interest rates with preference of young farmers and intergenerational succession of the farm is tax-free. Together with other incentives, those factors shall facilitate enter of young people to the sector. The aim of the paper is to assess whether the policy measures help the young farmers with setting-up of their business. Based on the primary survey on 510 young Czech farmers the most motivating for enter the sector were tax relief on transfer of the holding and top-up payment for young farmers. The farmers without background considered as sufficiently motivating the top-up payments more often than those with certain background who acknowledged more the top-up subsidies. Possible way how to facilitate the enter to the sector could be to keep the tax relief on farm transfer, to combine the measures for retirement and setting up of young farmers and provide investment subsidies or financial instruments for start-up. Top-up payments, despite motivational according to the farmers, are criticized as inefficient.
\end{abstract}

Keywords: ageing, agriculture, generation renewal, motivation, Rural Development Programme, subsidies, young farmers

\section{INTRODUCTION}

The ageing of the farmers' population is well acknowledged problem in the European Union (EU). The trend follows the development of the population: people tend to live longer and have fewer children. "The lack of young farmers puts under risk the survival of the sector itself, due to an inadequate rate of generational turnover in the sector," (Kontogeorgos et al., 2014).

A young farmer eligible for support is a farmer under 40 years of age, possessing adequate occupational skills, setting up on an agricultural holding for the first time, and being the head of the holding. It is rather difficult to assess the accurate number of young farmers in Member States of the EU. The lack of data was criticized by Zagata and Sutherland (2015) who pointed out that Farm Structure Survey is based on the age intervals under 35 years, 35 to 44, 45 to 54, 55 to 64,65 years and over. Since June 2018, the Eurostat has provided the data for farmers between 35 and 40 years of age, so it is now possible to assess the number of young farmers preciously. However, it is still not possible to distinguish the new entrants.

With this in mind, we can state that there were 2710 farms with manager under 40 years in the CR that accounted to $10.2 \%$ of the total number of farms and of older than 65 years (in fact retired) was 26.8\%. The generation renewal and ensuring the successors of older farm operators is crucial as the prosperity and sustainability of agriculture depends on an effective succession of farmland (Zou, Mishra and Luo, 2018). Therefore, young farmers are supported by policy 
measures. "Performing policy impact assessment at the regional level is expected to help policymakers to better understand the policy problems they face," (Bournaris et al., 2016) It is important to describe the mechanism how the policy incentives and conditions help to the generation renewal in agriculture. Therefore, the aim of the paper is to assess whether the policy measures help the young farmers with start-up of their business. The structure of the paper is as follows. Firstly, there is provided an overview of measures aimed at young farmers in the CR. Next section describes the primary survey and methods. Then the results are presented and discussed. Final section concludes and suggest policy implications.

EU set measures to help young farmers with their setting-up. Common Agricultural Policy offers special grants and incentives for farmers younger than 40 years. "Public support for re-structuring in agriculture typically follows two paths. Firstly, Farmer Early Retirement Schemes provide financial incentives to older farmers to retire prematurely. Secondly, New Entrant Schemes provides assistance to help establish a young farmer as head of an agricultural holding through either an interest subsidy on a farm development loan or as a capital grant.” (Davis, Caskie and Wallace, 2013). The first measure "has the objectives of facilitating new farmers' initial establishment and the structural adjustment of their holdings after initial setting up" (Kontogeorgos et al., 2014). The support is conditioned by submitting a business plan for farming and investment activity and to realize it within 5 years. It has been included in Rural Development Programmes (RDP) of the CR since 2007 and its continuation is envisaged in Proposal for a regulation of the European Parliament (EP) and of the Council establishing rules on support for Common Agricultural Policy (CAP) Strategic Plans and financed by the EAGF and EAFRD (European Commission (EC), 2018). Around 1400 projects were supported by RDP of the CR in 2007-2013 in the total amount 55.7 mil. EUR (Ekotoxa and IREAS, 2016). In new programming period so far 502 projects were approved in the $2^{\text {nd }}$ round in 2016 and $4^{\text {th }}$ in 2017 in the amount of 37.0 mil. EUR from total allocated budget 50.0 mil. EUR (EC, 2018).

"Farmer early retirement schemes provided financial incentives to older farmers to retire prematurely and transfer their farming activities to younger farmers" (Kontogeorgos et al., 2014). There was allocated around 37.0 mil. EUR in 2007-2013 but was repaid only 2.7 mil. EUR to 577 projects of farmers older than 55 years. The operation motivated the farmers to release 31.0 thous. ha of land (that means that average released land was 48.2 hectares). (Ekotoxa and IREAS, 2016). However, "current CAP lacks any incentives for older farmers to pass their businesses to younger generations" (EP, 2018).
Besides, there is a support also from the Pillar 1 in a form of top-up to the direct payments in a height of $30 \%$ to the original SAPS entitlement on maximally 90 ha. The subsidies were paid to around 4 thous. young farmers every year from 2015 to 2017, the total amount was almost 8.0 mil. EUR. Average supported area declined from 20.0 ha to 19.7 ha in 2017 and the number of projects increased.

Supporting Guarantee Agricultural and Forestry Fund (SGAFF) favourited young farmers when providing the grants on the interest rates. There are differences in the efficiency of different forms of support and in their perception by young farmers.

\section{MATERIALS AND METHODS}

The aim of the paper is to assess whether the policy measures policy measures are motivational enough and help the young farmers in the CR with start-up of their business. A primary survey was held by the Institute of Agricultural Economics and Information from 15 June to 1 July 2018. Over 5 thous. of young farmers in the CR were asked via electronic questionnaire. A sample contained of young farmers who have registered land in LPIS. We received 510 valid answers. The sample is described in detail in the Results and Discussion section.

The questionnaire examined several areas. First section collected data about the agricultural holding and last about the owners. In middle part, the farmers were asked whether they applied and received any public support and it in the case when they did not it was further examined what was the reason for not applying or not obtaining the subsidies. Consequently, the respondents assessed the type of the start-up and the policy incentives that should help to young farmers with the setting up of their business.

The characteristics of the supported and nonsupported (regardless if they applied for subsidies or not) holdings were statistically described and the differences between opinions of those groups were tested. As it was seen from histograms and proved by Shapiro-Wilk normality test $\left(\mathrm{H}_{0}\right.$ : the distribution of variable is normal, $\mathrm{H}_{\mathrm{A}}$ : non $\mathrm{H}_{0}$ ), the data about the acreage, length of existence and number of employees were not normally distributed at 5\% level of significance. Hence, non-parametric Wilcoxon rank-sum test was used to test the arithmetic means of the variables. Null hypothesis assumed equality $\left(\mathrm{H}_{0}: \mu_{0}=\mu_{1}\right)$, alternative the difference $\left(\mathrm{H}_{\mathrm{A}}: \mu_{0} \neq \mu_{1}\right)$ at $5 \%$ level of significance

The respondents were also questioned whether they applied for the subsidy from RDP. If they applied, then they were asked on the type of subsidies: investment subsidies (previous and current RDP) or setting-up subsidies (previous and current RDP). It was asked further, what type of subsidies they received to see the success rate (obtained vs. applied subsidies). If they were not 
received, there were further examined the reasons why. If the farmers did not apply and did not consider the application in the future, we surveyed the reasons why the subsides were not attractive for them. Similarly, if they did not apply, but they were considering it in the future, we surveyed the reasons, why they postponed their decision.

In next section, the farmers assessed whether the agricultural measures and factors are sufficiently motivating for the start-up of young entrepreneurs in agriculture on a scale: Certainly yes (1 point), Rather yes (2 points), Rather not (3 points), Certainly not (4 points), I cannot assess (0 points). The types of measures were: RDP - start-up support for young farmers; RDP - investment modernization support; SGAFF - higher subsidy on interest rate; 30\% top-up to the basic direct payments; exemption from the tax on the family transfer of property; vocational education system; level of professional advisory services. The weighted average (without I cannot assess) was calculated. In the following open question, the farmers suggested policy measures that would help them to start with agriculture.

The data were statistically described (by relative frequencies) and grouped to contingency tables. It was tested, whether the type of policy measure or other factors depends on the gender or on the type of start-up. $\chi^{2}$ goodness of fit test was used. The null hypothesis is independence of the variables $\left(\mathrm{H}_{0}: \pi_{i j}=\pi_{i}, \pi_{j}\right.$; where $\left.1 \leq i \leq r, 1 \leq j \leq s\right)$ and alternative hypothesis is $\mathrm{H}_{\mathrm{A}}$ : non $\mathrm{H}_{0}$. If value of $G$ statistics is lower than tabled value of $\chi_{[1-a]}^{2}$ then null hypothesis is not rejected, and the variables are independent. Data were processed in Stata 15.1 and MS Excel.

\section{RESULTS AND DISCUSSION}

The questionnaire was filled-in by 382 men and 128 (25.1\%) women, from which 94.7\% was physical persons. 27 legal persons were of various types. The average age of the respondent was 33 years. There were 175 companies with livestock production, 133 with pure crop production and 202 with mixed.

Agricultural holdings of a young farmers had 42.4 ha of Utilize Agricultural Area (UAA) on average, from which $62.4 \%$ was rented. However, the median was only 18 ha of UAA, from which $44.4 \%$ was rented. There is a relatively small number of large holdings and many smaller enterprises - i. e. farmers without land on one side and maximal acreage 1000 ha on the other side. Majority of agricultural entrepreneurs was registered in 2015 (20\%) and 2016 (19.8\%); 80.4\% of them started their farming activities already in the year when they registered. Young farmers' businesses operated on average for 5.2 years. The average existence of an enterprise since registration was shorter (4.9 years) as the farm may be operating longer, but its existence under the new young farmer is shorter. In 39.4\% cases the household of the farmers had 4 members including the farmer. Then there were households with 3 members and 5 members.

There were 219 farmers (42.4\%) who started without background and 291 respondents who had at least some (41.8\% took it over/5.1\%, inherit from parents or other relatives, 4.1\% purchased from parents or other relatives and 1.8\%from other farmer, $1.2 \%$ partially took over from parents or other relatives and same proportion joined family farming, $0.26 \%$ had other background. In $29.0 \%$ of cases the farms were overtaken from farmers older than 55 years. Majority of farmers (46.1\%) started to farm up to 10 years from graduation, while $31.0 \%$ started later and 22.9\% during studies.

Over half (52.4\%) of respondents applied for a subsidy. The success rate was high $-83.1 \%$. Out of those 267 applicants, 45 (17\%) have not received any subsidy at the end. There were 35 farmers who applied for more type of subsidies but obtained only some of them. $44.1 \%$ of respondents already applied for Support for setting up of young farmers' businesses in current programming period and 38.9\% of them have already received the subsidy. In previous period (2007-2013), 17.3\% of the respondents requested and $15.4 \%$ were awarded the start-up grant. Application for subsidies from the measure investments to farms from the RDP 2014-2020 appeared in 29.5\% cases and was received in $25.2 \%$ cases. The most common was the combination of investment grant and start-up subsidy in current RDP.

According to the results of Shapiro-Wilk test, acreage, length of existence and number of employees were not normally distributed. P-values were lower than 0.05 and the null hypothesis was rejected (see Tab. I)

Therefore, a non-parametric Wilcoxon rank-sum test was used to examine the difference between arithmetical means of samples of supported and non-supported farms. If the p-value is lower than 0.05, the null hypothesis that the means of both groups are equal is rejected. Results are displayed at Tab. II.

I: Results of Shapiro-Wilk normality test

\begin{tabular}{lccrrc}
\hline \multicolumn{1}{c}{ Variable } & Observations & $\mathrm{W}$ & $\mathrm{V}$ & $\mathrm{z}$ & Prob > z \\
\hline Acreage & 510 & 0.4487 & 188.8060 & 12.6090 & 0.0000 \\
Length of existence & 510 & 0.8442 & 53.3610 & 9.5690 & 0.0000 \\
Number of employees & 510 & 0.6722 & 112.2590 & 11.3580 & 0.0000 \\
\hline
\end{tabular}

Source: own elaboration 
II: Results of Wilcoxon rank-sum test

\begin{tabular}{|c|c|c|c|c|c|c|c|}
\hline \multirow{2}{*}{ Non sup. /supported } & \multirow{2}{*}{ Observ. } & Rank sum & Expected & Rank sum & Expected & Rank sum & Expected \\
\hline & & \multicolumn{2}{|c|}{ Acreage } & \multicolumn{2}{|c|}{ Length of existence } & \multicolumn{2}{|c|}{ Number of employees } \\
\hline 0 & 288 & 65720 & 73584 & 71365 & 73584 & 69140 & 73584 \\
\hline 1 & 222 & 64586 & 56721 & 58941 & 56721 & 61166 & 56721 \\
\hline Combined & 510 & 130305 & 130305 & 130305 & 130305 & 130305 & 130305 \\
\hline Unadjusted variance & & \multicolumn{2}{|c|}{2722608} & \multicolumn{2}{|c|}{2722608} & \multicolumn{2}{|c|}{2722608} \\
\hline Adjustment for ties & & \multicolumn{2}{|c|}{-22508} & \multicolumn{2}{|c|}{-48814} & \multicolumn{2}{|c|}{-454885} \\
\hline Adjusted variance & & \multicolumn{2}{|c|}{2700100} & \multicolumn{2}{|c|}{2673794} & \multicolumn{2}{|c|}{2267723} \\
\hline $\mathrm{z}$ & & \multicolumn{2}{|c|}{-4.7860} & \multicolumn{2}{|c|}{-1.3570} & \multicolumn{2}{|c|}{-2.9510} \\
\hline P-value & & \multicolumn{2}{|c|}{0.0000} & \multicolumn{2}{|c|}{0.1747} & \multicolumn{2}{|c|}{0.0032} \\
\hline
\end{tabular}

Source: own elaboration

Supported farmers had statistically significantly higher acreage (55.4 ha) than those who did not apply or get the subsidies (32.2 ha). This suggests that the subsidies are not equally distributed among small and larger holdings. Ekotoxa and IREAS (2016) were also concerned about this fact and recommended to "pay attention to the distribution of supports, e.g. support higher participation of smaller farmers".

The differences in the length of formal existence of the holding was equal in both groups (4.6 years of supported vs. 5.2 of non-supported). Ekotoxa and IREAS (2016) noted that current requirements in the operation support transfer in family rather than new holdings due to too high minimum level of standard output that must be achieved when applying for support.

The farms that obtain subsidies are larger also in terms of the number of employees, because null hypothesis about equality was rejected. The reasons why farmers did not get the subsidy were many. Mostly (44 cases), the farmers did not get enough preferential points for the project. 13 applicants had administrative deficiencies, from which 7 did not produce required documents. Others were not eligible, stopped during the proceedings or did not know the reason. Remaining 15 were still under examination.

For farmers who had not yet asked for subsidies and were preparing to apply was the biggest obstacle the administrative burden (for 41.5\% from 106 respondents). Further $34.9 \%$ farmers could not have applied for subsidies because they were not an eligible applicant. The respondents sometime objected that subsidies are aimed at already established farmers and not on those who start "from scratch". Lack of information was the cause of no application in 13.2\% of cases. Lack of time in $7.5 \%$ cases.

The applicants were not eligible as the economic size of the farm did not meet the minimum and maximum standard production limits or the applicants did not possess required minimum agricultural qualification, were also registered over 2 years or combination.
We also asked $26.9 \%$ of respondents who indicated that they did not and will not apply for grant for the reasons. Mostly (38.3\%), respondents were discouraged by administrative burdens. Additionally, in 37 cases the respondent was not an eligible applicant. From this, in 31 cases the registration of the farm was longer than 2 years, in 3 cases the thresholds of the production were not met, and in 3 cases was a cause the combination. For 10 applicants the conditions for obtaining the grant were unfulfillable, of which 2 farmers had too small farm. Furthermore, 5 respondents did not achieve sufficient income from agricultural activities. Some respondents also did not want to apply or did not know why they did not apply. 16 respondents did not know about the possibilities of subsidy programs. In few cases, there was not a call for subsidy in suitable time.

The results are displayed at Fig. 1. According to $14.3 \%$ of respondents, RDP start-up support was certainly a motive to set up business; for $23.5 \%$ it was rather yes. On the other side, rather not answer was more frequented $-21.4 \%$ and certainly not $23.3 \%$. The rest could not assess this issue. It is surprising that this measure is not considered more motivational. Also, the help to firm's performance is unclear in measurable terms - see Pechrová (2015). Investment support was seen more positive (certainly and rather yes in $40.2 \%$ cases and certainly and rather not in 40.4\%) but could not be assessed in $19.4 \%$ cases.

Higher subsidy on interest rates for young farmers under investment measure Farmer provided by SGAFF was a motivator according to $19.0 \%$ (certainly yes) or $26.3 \%$ (rather yes) of the respondents. $21.2 \%$ could not evaluate the measure, but $19.8 \%$ thinks that it rather not and $13.7 \%$ that certainly not motivate to start-up in the sector. EP (2018) calls for introduction of subsidized interest rates on loans or insurance on new entrant loans to help them to obtain enough capital for their start-up and stabilize their income. 
The top-up payment to the basic SAPS entitlements in height of $30 \%$ were motivating in $22.2 \%$ cases (certainly yes), $34.5 \%$ rather yes. It might be because they are not bounded by any business plan or other requirements. That is a subject to criticism by Matthews (2013). "A rather extraordinary feature of the Commission's proposal was that absolutely no obligations are put on young farmers other than that they should be under 40 years of age" (Matthews, 2013). It is left up to member states whether they want to impose the criteria for young farmers as those set out for the Pillar 2 business start-up aid. The support is easier to obtain for farmers, but it is harder to track its effects. "There is no good evidence that providing additional income support for a limited period of time in Pillar 1 is and effective use of funds either to promote generational renewal or to improve farm productivity”. (Matthews, 2013) Current Direct Payment Schemes also exacerbate the land access problem, as it dis-incentivises land sales and rental and supports land speculations (EP, 2018). Also, European Council of Young Farmers (CEJA) suggests that top up for all young farmers must be provided on completion of a farm business development plan (CEJA, 2017). According to Matthews (2017) uniform area-based decoupled payments paid on hectare of agricultural land are an ineffective policy instrument as they increase competition for land, push up land rents and prices, slow down structural change, make entry for young farmers more difficult and put downward pressure on product prices. Hence, despite that top-up subsidies are considered as motivational by the farmers, they might not be efficient.

The tax relief on the acquisition of property in a family transfer was certainly motivating for $29.6 \%$ respondents and rather for $27.1 \%$ respondents. $14.7 \%$ answered rather not, $7.6 \%$ certainly not and 21.0\% did not assess it.
Vocational education system must be improved, it is sufficiently motivational only according to $9.8 \%$ certainly and to $19.6 \%$ rather. $28.4 \%$ considered it as rather not motivational, $15.9 \%$ certainly not motivation and 26.3\% did not assessed it. Level of professional advisory services was sufficiently motivation for 10.0\% (certainly) and 23.7\% (rather). Contrary to that, rather not was the answer in $25.5 \%$, certainly $16.5 \%$. $24.3 \%$ did not assess it at all. EP (2018) suggest that there should be "further training available to new entrants and young farmers, particularly in the areas of business management and financial skills”.

After the exclusion of the answer I cannot assess it was calculated, which measure will get the best mark. Mostly, in the view of young farmers, will help the relieve of the tax on the acquisition of property in the case of a family transfer - it got the best mark 2.0. Second best motivator was the top-up payment for young farmers (2.2 points). This is not in-line with the findings of Carbone and Subioli (2008) for Italy: "the size of the payment provided by the EU measure for young farmers offers an ineffective incentive to attract young people into the sector, and it is also insufficient to finance an increase in the competitiveness of the existing holdings through the familiar turnover within the farm”. Then there was highly evaluated the higher subsidy on interest rate for younger farmers. This seems as more effective way, how to support young farmers. Davis, Caskie and Wallace (2013) after comparing the results under the fixed grant proclaimed that the interest subsidy policy appeared much better value for money. On the contrary, the system of vocational education is not considered that important (2.7 points), but almost $26.3 \%$ of the respondents did not comment. RDP start-up support was seen as less motivational (2.7 points).

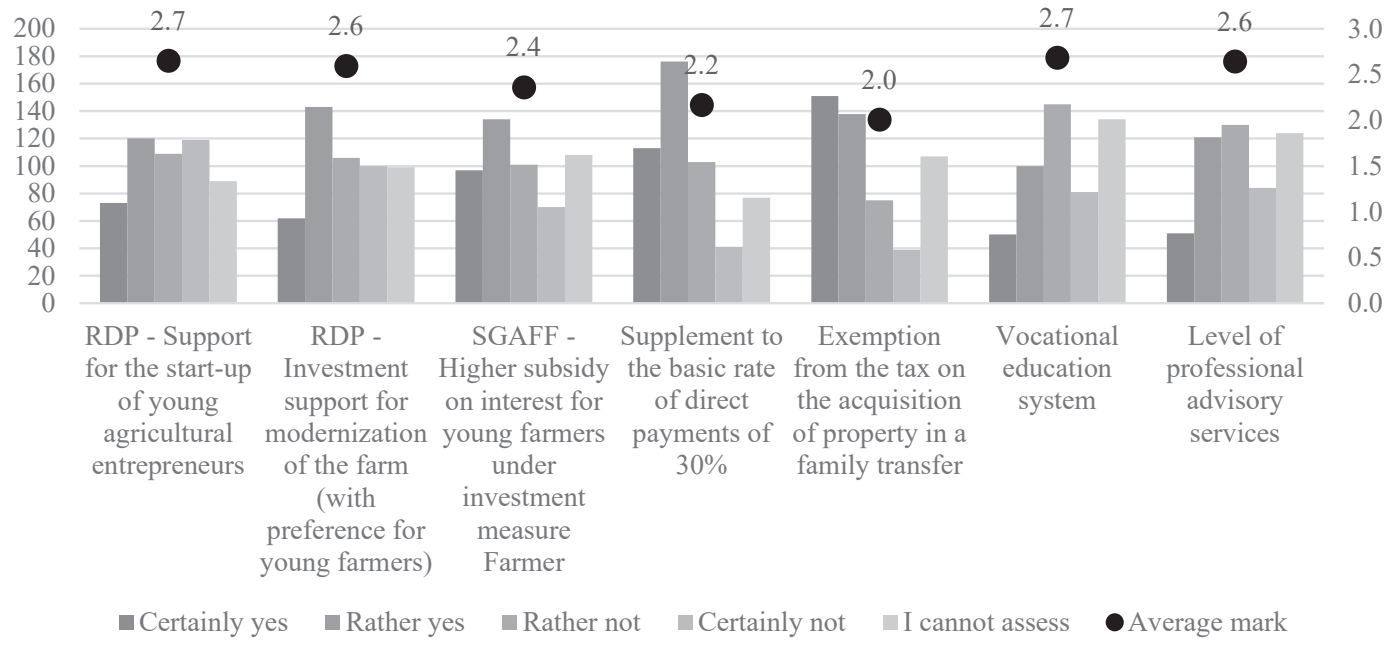

1: Are the agricultural policy measures and other factors sufficiently motivating for the start-up of young farmers? Source: own elaboration based on data from primary survey (2018) 
III: Results of $\chi^{2}$ goodness of fit test $\left(\chi_{[1-a]}^{2}{ }^{v=1}=9.488\right)$

\begin{tabular}{clcl}
\hline \multicolumn{2}{c}{ Gender } & \multicolumn{2}{c}{ Background } \\
\hline G - statistic & Result & G - statistic & \multicolumn{1}{c}{ Result } \\
\hline 8.1671 & independent on gender & 8.8590 & independent on background \\
2.9696 & independent on gender & 7.3076 & independent on background \\
8.2918 & independent on gender & 8.2510 & independent on background \\
28.9907 & dependent on gender & 13.8671 & dependent on background \\
9.6138 & dependent on gender & 12.2442 & dependent on background \\
8.3593 & independent on gender & 7.5960 & independent on background \\
9.4376 & independent on gender & 12.2319 & dependent on background \\
\hline
\end{tabular}

Source: own elaboration

Whether the type of policy measure or other factors depends on the gender or on the type of start-up was tested by $\chi^{2}$ goodness of fit test in the contingency table. Results are displayed in Tab. III

The opinion depends on the gender only in the case of top-up to direct payments and exemption from the tax. In both cases men tend to answer rather and certainly yes more than women.

The dependence was found between those young farmers who had certain background when they started and those who did not in case of opinion on top-up to direct payments and exemption from the tax. The farmers without background thought more often that top-up subsidies are motivating enough. According to their opinion, the exemption from the tax is less motivating (but they did not have personal experience). Farmers with certain background answered more often that the level of advisory is sufficient for young farmers to start with agriculture.

In the following open question, the farmers suggested other measures that would help them such as facilitating the administrative bureaucracy burden. It is in line with findings of EP (2018) where it is suggested that "it is necessary to reduce administrative procedures related to the existing measure for young farmers". Farmers further stressed that the support shall be targeted also on smaller farmers (e.g. also to those who do not reach the minimum threshold of standard output). They also suggested relieves on social insurance, existence of exchange programmes and quality advisory service.

We can conclude that subsidies or grants is not the only possible way, how to support the generation renewal. Also, other issues are important. The policy-makers shall know the main motivators and barriers which facilitate or hinder the entrance of new comers to the sector. This could help them to create wider scope of policy measures that attract young people to the sector and ease their start-up.

EP (2018) also calls for reconsideration of the implementation of measures to "include pension related regulations and offering pension opportunities to retiring farmers. Current proposal of the Regulation enables to fund the farm transfer from a farmer in retirement age to a young farmer. However, the details and eligibility criteria of the intervention are not set yet. In our research $29.0 \%$ of farmers overtook the farm from a farmer older than 55 years. Hence, as also highlighted by Lobley, Baker and Whitehead (2010) there is a need of future research in planned retirement and motivation of farm transfer. The examination of the motivation of retirement of older farmers shall be also subject of future research.

\section{CONCLUSION}

Generation renewal has been addressed by Common Agricultural Policy (CAP) and national agricultural policies. There are start-up or investment subsidies, financial instruments or tax relieves that shall facilitate the enter of young people to the sector. The aim of the paper is to assess whether the policy measures are motivational enough and help the young farmers with start-up of their business. The assessment was done by the farmers themselves in a primary survey. Over half of respondents (52.4\% from 510) applied at least for one type of CAP subsidy. The success rate was 83.1\%. Supported farms were statistically significantly larger in terms of the acreage and number of employees, but they were registered into the register of agricultural entrepreneur later. On the other hand, the difference in the length of existence between supported and non-supported group were not statistically significantly different. Mostly, the respondents were discouraged from the possibility of applying for subsidy by administrative burdens, but some of them are thinking about applying in the future. 
In the view of young farmers, the most motivational is the relieve of the tax on the acquisition of property in the case of a family transfer, top-up subsidies for young farmers on land and higher subsidies on interest rates provided by SGAFF.

The farmers without background thought statistically significantly more often than with background that top-up subsidies for young farmers are motivating enough. On the other hand, the farmers with certain background though more often that the exemption from the tax is sufficiently motivating, which can have connection with the fact that 29.0\% of young farmers overtook the farm from a farmer older than 55 years. To facilitate the enter to the sector should be kept the tax relief on farm transfer, combined measures for retirement and setting up of young farmers and provided investment subsidies for start-up.

\section{Acknowledgements}

The paper was supported by the Ministry of Agriculture of the Czech Republic, institutional support MZE-RO0918, Internal Research Project No. 1113/2019 and from the long-term institutional support of University of Economics Prague, Faculty of Informatics and Statistics.

\section{REFERENCES}

BOURNARIS, T., MOULOGIANNI, C., ARAMPATZIS, S. et al. 2016. A knowledge brokerage approach for assessing the impacts of the setting up young farmers policy measure in Greece. Environmental Impact Assessment Review, 57: 159-166.

CARBONE, A. and SUBIOLI, G. 2008. The Generational Turnover in Agriculture: The Ageing Dynamics and the EU Support Policies to Young Farmers. In: Proceedings of $109^{\text {th }}$ EAAE Seminar "The CAP After the Fischler Reform: National Implementations, Impact Assessment and the Agenda for Future Reforms". EAAE, 20-21 November. Viterbo: EAAE, pp. 1-19.

CEJA. 2017. Young Farmers are Key in the Future CAP. [Online]. Brussels: European Council of Young Farmers. Available at: http://www.ceja.eu/wp-content/uploads/2017/05/Final-Young-Farmers-areKey-in-the-Future-CAP-BW.pdf [Accessed: 2018, August 11].

DAVIS, J., CASKIE, P. and WALLACE, M. 2013. Promoting structural adjustment in agriculture: The economics of New Entrant Schemes for farmers. Food Policy, 40(C): 90-96.

EC. 2018a. Proposal for a "Regulation of the European Parliament and of the Council" establishing rules on support for strategic plans to be drawn up by Member States under the Common agricultural policy and financed by the European Agricultural Guarantee Fund and by the European Agricultural Fund for Rural Development. [Online]. Brussels: European Commission. Available at: https://ec.europa.eu/ info/law/better-regulation/initiatives/com-2018-392_en [Accessed: 2018, August 5].

EC. 2018b. Factsheet on 2014-2020 Rural Development Programme for the Czech Republic. [Online]. Brussels: European Commission. Available at: https://ec.europa.eu/agriculture/sites/agriculture/ files/rural-development-2014-2020/country-files/cz/factsheet_en.pdf [Accessed 2018, August 5].

EKOTOXA and IREAS. 2016. Ex-post evaluation of the Rural Development Programme of the Czech Republic for period 2007-2013. [in Czech: Ex-post hodnocení Programu rozvoje venkova ČR za období 2007-2013, Závěrečná zpráva]. Praha: Ministerstvo zemědělství České republiky. [Online]. Prague: Ministry of Agriculture. Available at: http://eagri.cz/public/web/file/568806/Ex_post_PRV_2007_13_ ZZ_final.pdf [Accessed 2018, August 12].

EP, European Parliament. 2018. REPORT on the implementation ofCAPyoung farmers' tools in the EU after the 2013 reform (2017/2088(INI)). European Parliament. [Online]. Available at: http://www.europarl. europa.eu/sides/getDoc.do?type=REPORT\&reference=A8-2018-0157\&format=XML\&language=EN [Accessed: 2018, August 5].

EUROSTAT. 2018. Farm indicators by agricultural area, type of farm, standard output, sex and age of the manager and NUTS 2 regions [ef_m_farmang]. Eurostat. [Online]. Available at: https://ec.europa. eu/eurostat/data/database [Accessed 2018, Aug 4].

KONTOGEORGOS, A., MICHAILIDIS, A., CHATZITHEODORIDIS, F. et al. 2014. "New Farmers” a Crucial Parameter for the Greek Primary Sector: Assessments and Perceptions. Procedia Economics and Finance, 14: 333-341.

LOBLEY, M., BAKER, J. R. and WHITEHEAD, I. 2010. Farm Succession and Retirement: Some International Comparisons. Journal of Agriculture, Food Systems, and Community Development, 1(1): 49-64.

MATTHEWS, A. 2013. Wasting Money on Young Farmers? CAP Reform.eu. [Online]. Available at http:// capreform.eu/wasting-money-on-young-farmers [Accessed: 2018, August 1]. 
MATTHEWS, A. 2017. Why further reform of the CAP is needed now. CAP Reform.eu. [Online]. Available at: http://capreform.eu/why-further-reform-of-the-cap-is-needed-now [Accessed: 2018, August 1].

PECHROVÁ, M. 2015. The profitability and technical efficiency of young farmers supported from Rural Development Programme. In: Proceedings of the $33^{\text {rd }}$ International conference on Mathematical Methods in Economics 2015. University of West Bohemia, 9-11 September. Cheb: University of West Bohemia, Faculty of Economics, pp. 618-623.

ZAGATA, L. and SUTHERLAND, L. 2015. Deconstructing the 'young farmer problem in Europe': Towards a research agenda, Journal of Rural Studies, 38: 39-51.

ZOU, B., MISHRA, A. K. and LUO, B. 2018. Aging population, farm succession, and farmland usage: Evidence from rural China. Land Use Policy, 77: 437-445.

Contact information

Marie Šimpachová Pechrová: simpachova.marie@uzei.cz Ondřej Šimpach: ondrej.simpach@vse.cz 